\title{
Evaluation of operational performance as a means for deciding about intermodal passenger transport improvements in urban environments
}

\author{
Avaliação de desempenho operacional como meio de decisão para \\ aprimoramento de viagens intermodais no transporte de passageiros em \\ ambientes urbanos
}

\author{
Luiz Guimarães Ribeiro Neto1, Maria Leonor Alves Maia² \\ 1Federal University of Pernambuco, Pernambuco - Brazil, luiz.neto@igarassu.ifpe.edu.br \\ 2Federal University of Pernambuco, Pernambuco - Brazil, nonamaia@gmail.com
}

\section{Recebido:}

30 de outubro de 2020

Aceito para publicação:

5 de setembro de 2021

Publicado:

25 de agosto de 2021

Editor de área:

Antônio Nélson Rodrigues da Silva

\section{Keywords:}

Intermodality.

Passenger transport.

Performance.

Operational.

Palavras-chave:

Intermodalidade.

Transporte de passageiros.

Performance.

Análise operacional.

DOI:10.14295/transportes.v29i2.2487

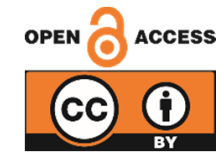

\begin{abstract}
Regarding intermodal urban transport systems for passengers, there is no recognized standard for performance analysis. Detecting the weaknesses of such systems can allow managers to carry out more assertive, corrective actions and make them more attractive to users. The main objective of this article is to propose a model for evaluating the performance of intermodal travel for passengers in urban environments. The exploratory factor analysis was the method used to evaluate and classify the variables that constitute the proposed standard. The results show that the factors related to travel time, infrastructure and available information are the most important characteristics for the interviewed public. The operational performance analysis carried out in the Metropolitan Region of Recife, state of Pernambuco, Brazil, reveals the difficulties faced by the citizens while making an intermodal trip, which may be contributing to a reduction in the number of users of the passenger transport system.
\end{abstract}

\begin{abstract}
RESUMO
Em relação ao sistema intermodal de transporte urbano de passageiros, não há um padrão reconhecido para análise do seu desempenho. Detectar os pontos de fragilidade desse sistema irá permitir aos gestores a realização de ações corretivas mais assertivas, tornando-o mais atrativos para os usuários. $O$ objetivo principal desse artigo é propor um modelo para avaliação de performance de viagens intermodais no transporte de passageiros em ambientes urbanos. A análise fatorial exploratória foi o método utilizado para avaliação e classificação das variáveis constituintes do padrão proposto. Os resultados encontrados asseguram que os fatores relativos a tempo da viagem, infraestrutura e informações disponíveis são as características mais importantes para o público entrevistado. A análise de desempenho operacional realizada na Região Metropolitana de Recife, Pernambuco, Brasil, revela as dificuldades enfrentadas pelos cidadãos para realizar uma viagem intermodal, o que pode estimular a redução no número de usuários do sistema de transporte passageiros.
\end{abstract}

\section{INTRODUCTION}

Since there is a natural limitation in relation to the number of direct trips made by public transport, there is a need for the user to use different modes of transport to complement his/her daily commutes. In these cases, it is necessary to guarantee the availability of intermodal trips. This allows the same commute to be composed of more than one mode of transport, enabling 
the integration between different modes of public transport, as well as between public transport and individual motorized and non-motorized transport.

Studies related to intermodality focus predominantly on the performance of the public transport system during the process of intermodal transfers. However, there is limited research related to the evaluation of the performance of the entire network necessary to guarantee a trip constituted by the interconnection of different forms of displacement. This is an important gap in the research, as users may identify restrictions at different stages of an integrated passenger transport operation.

The main objective of this study is therefore to propose a model for evaluating the operational performance of intermodal passenger travel in urban environments. Based on the definition of the most relevant factors used in the development of intermodality, a scale and an index is determined to be utilized in the assessment of the operational performance. This in turn will demonstrate whether the projected mobility network and the requirements for its use are compatible with the needs of users.

Comparing to previous research, the model presented in this study expands the field of analysis and incorporates the proposed evaluation scale, in addition to exchange points, the various characteristics necessary to ensure the best sharing of space along public transit-ways and the consequent integration of the different means of transport, responsible for complementing a door-to-door trajectory. The exploratory factor analysis was the method used to validate, classify and define the weights of the variables, while quartile analysis was used to define the order of priority of the factors with the greatest need for managerial intervention. The field research was carried out in the Metropolitan Region of Recife, state of Pernambuco, Brazil.

To better understand, this study is subdivided into 3 sections, in addition to the introduction: section 2 presents a literature review with the general definitions related to the concept of intermodal displacement. It highlights the advantages and difficulties resulting from its implementation and presents the characteristics that stimulate intermodal passenger transport in urban environments - throughout the entire route traveled by the user and not only in the region surrounding the interchange locations. Section 3 describes the methodology used to prepare the evaluation model. Finally, the last section analyzes the results found.

\section{PERFORMANCE EVALUATION OF INTERMODAL TRIPS USING PASSENGER TRANSPORT IN URBAN ENVIRONMENTS}

Intermodality in passenger transport is the use of more than one means of transport, interconnected in a coordinated way, to complement a single trip (Scheiner, Chatterjee \& Heinen, 2016). Encouraging the behavior of intermodal travel, based on public transport, has become a necessary reality as it allows for the construction of a more sustainable mobility network, organized around the optimum use of public circulation spaces, as well as the preservation of available natural resources and pollution reduction.

Moreover, it provides the user with the power to choose between the quickest, cheapest or most comfortable way to move around, since the positive aspects of each means of transport are stimulated and their negative factors minimized (Litman, 2017).

Despite the benefits resulting from the implementation of an integrated mobility network, Willing, Brandt \& Neumann (2017) emphasize that, in addition to the challenges related to the 
population's travel habits, some technical barriers for its implementation remain. For instance, switching between modes of transport can lead to an increase in the average travel time, reducing the customer's interest in the service.

Another condition observed is that the general use of intermodal transport may result in an increase or reduction of the fare of the trip. Finally, the lack or limited information available to potential users about alternative forms of displacement is also an issue to be overcome.

Nathanail et al. (2018) highlight that the integration of an intermodal network occurs mainly at interchange points, defined as the hub of a transport system and responsible for determining continuous mobility. As will be presented below, the literature review shows that most studies related to intermodality focus on how these locations influence the efficiency of the trip and consequent user satisfaction.

Chowdhury \& Ceder (2013) identified that accessibility to the transport network and location of interchange points are the factors with the greatest influence on the willingness of passengers to use an integrated public transport system in New Zealand. Pitsiava-Latinopoulou and Iordanopoulos (2012) concluded that the spatial location and synchronization of services offered in Greece are the aspects identified by the population that have the greatest impact on the service level of the interchange terminals and that most influence their decision regarding modal choice.

Hernandez \& Monzon (2016) and Monzón, Hernández \& Di Ciommo (2016) developed a satisfaction survey among European travelers and placed the main features of the interchange points into two dimensions: physical size and local impacts (related to the local development plan). Lucietti, Hoogendoorn \& Cré (2016) analyzed, in European cities, procedures for the design and operation of urban transport exchanges with the aim of promoting greater efficiency at the points of integration.

Lois, Monzón \& Hernández (2018) reported that information and security are the main dimensions that explain users' satisfaction with the transport interchange points. Correia (2017) also highlighted the clarity of the information made available to the user (travel times, different transportation alternatives, prices charged per trip) as a relevant instrument in decision-making about travel choice.

The general operational requirements (technical characteristics necessary to carry out an interchange operation between modes of transport: integration of operation schedules, access and comfort) are known and used at the interchange points. However, it is necessary to go further and incorporate other issues into the same model of analysis, such as the integrated planning, operation and control of activities of the various modes of transport, coordinated with the management of land use and occupation. Only the consolidation of these aspects allows for the establishment of a fully Integrated Passenger Transport System (IPTS).

According to Janic (2010), the formation of an IPTS encompasses different modes of transport, forming a single transport operation, that presents multiple connections of origin and destination. Therefore, depending on the formation of an interconnected network, there is a need to identify how the relationships established between the various forms of transport throughout the urban environment interfere with the performance of an intermodal journey. Chowdhury et al. (2018) classify the IPTS according to its operational characteristics, having as the main element of analysis the transfer process through its five main attributes, these being: 
a) Network integration: representing the necessary connections to interconnect the various accesses existing in the city, in order to provide a wide range of destinations.

b) Integration of fares: guaranteeing unified forms of payment, regardless of the operator or mode of transport utilized by the user of the system.

c) Integration of information: providing information to passengers in real-time, presenting connection possibilities that provide greater flexibility for making trips, and responding to system delays and/or malfunctions.

d) Physical integration of stations: definition of a shared infrastructure in which the interchange hubs guarantee greater efficiency of the network, regardless of the company or mode of transport used.

e) Temporal integration of the operation: when the different modes of transportation are planned to complement each other, transfer times are minimized by this intermodal network, allowing a reduction in the waiting time for users to complete their journey.

Based on the IPTS classification proposed by Chowdhury et al. (2018), Table 1 shows the variables identified in the literature which help constitute a more efficient passenger transport network in urban environments, improving intermodal travel and presenting public transport as its structuring element.

Table 1 - Basic variables for forming an integrated passenger transport network in urban environments

\begin{tabular}{|c|c|c|}
\hline $\begin{array}{l}\text { Classification of } \\
\text { the IPTS }\end{array}$ & $\begin{array}{l}\text { Variables necessary for forming a passenger transport network in urban } \\
\text { environments, which allows intermodal travel }\end{array}$ & Reference \\
\hline \multirow{4}{*}{$\begin{array}{l}\text { a) Network } \\
\text { Integration. }\end{array}$} & $\begin{array}{l}\mathrm{X}_{1} \text { : Access conditions: easy access for all users to reach circulation places } \\
\text { of public transport (PT) without obstacles in the access roads, and } \\
\text { security against mugging and theft. }\end{array}$ & $\begin{array}{l}\text { Becker \& Albers (2016); Wang, } \\
\text { Monzon \& Di Ciommo (2015). }\end{array}$ \\
\hline & $\begin{array}{l}\mathrm{X}_{2} \text { : Connectivity: maintaining a maximum distance of } 800 \text { meters } \\
\text { between public transport boarding stations. }\end{array}$ & Woldeamanuel \& Kent (2015). \\
\hline & $\mathrm{X}_{3}:$ Exclusive corridors for PT on public roads. & Ferraz \& Torres (2001). \\
\hline & $\begin{array}{l}\mathrm{X}_{4} \text { : Physical segregation for the movement of pedestrians, bicycles and } \\
\text { vehicles on public roads. }\end{array}$ & $\begin{array}{l}\text { Olekszechen, Battiston \& Kuhnen } \\
\text { (2016); Barnfield \& Plyushteva } \\
\text { (2016). }\end{array}$ \\
\hline \multirow{2}{*}{$\begin{array}{l}\text { b) Fare } \\
\text { Integration. }\end{array}$} & $\begin{array}{l}X_{5}: \text { Smart cards used for all services: single rechargeable ticket for com- } \\
\text { mon use in the different modes of transport and bicycle rental. }\end{array}$ & Chowdhury \& Ceder (2013). \\
\hline & $\begin{array}{l}\mathrm{X}_{6} \text { : Integrated modes of transport (bus, train and subway), allowing free } \\
\text { transfers, without any additional charge for transfers. }\end{array}$ & $\begin{array}{l}\text { Redman et al. (2013); Chowdhury } \\
\text { \& Ceder (2013). }\end{array}$ \\
\hline \multirow{2}{*}{$\begin{array}{l}\text { c) Information } \\
\text { integration. }\end{array}$} & $\begin{array}{l}\mathrm{X}_{7} \text { : Mobile sites or applications that provide real-time information related } \\
\text { to passenger transport. }\end{array}$ & $\begin{array}{l}\text { Guirao et al. (2015); Eboli \& Maz- } \\
\text { zulla (2012). }\end{array}$ \\
\hline & $\begin{array}{l}\mathrm{X}_{8} \text { : Visual communication with information about the PT at the transport } \\
\text { connection points. }\end{array}$ & $\begin{array}{l}\text { Eboli \& Mazzulla (2012); Mano \& } \\
\text { Ribeiro (2015). }\end{array}$ \\
\hline \multirow{6}{*}{$\begin{array}{l}\text { d) Physical } \\
\text { integration of } \\
\text { stations. }\end{array}$} & $\mathrm{X}_{9}$ : Bicycles for rent near PT boarding stations. & Dragu, Roman \& Roman (2013). \\
\hline & $\mathrm{X}_{10}$ : Public transportation adapted to transport bicycles. & Eboli, Fu \& Mazzulla (2016). \\
\hline & $\mathrm{X}_{11}$ : Bicycle parking spaces near PT boarding stations. & $\begin{array}{l}\text { Buehler (2012); Piatkowski et al. } \\
\text { (2014). }\end{array}$ \\
\hline & $\mathrm{X}_{12}$ : Parking for automobiles and motorcycles close to boarding stations. & Brons, Givoni \& Rietveld (2009). \\
\hline & $\mathrm{X}_{13}:$ Taxi service near boarding stations. & Dragu, Roman \& Roman (2013). \\
\hline & $\begin{array}{l}\mathrm{X}_{14} \text { : Comfort: well-being or satisfaction promoted at integration points, } \\
\text { such as attention to users, availability of shelter and seats, cafeterias, } \\
\text { toilets and hygiene. }\end{array}$ & $\begin{array}{l}\text { Hernandez \& Monzon (2016); Fu } \\
\text { et al. (2017). }\end{array}$ \\
\hline \multirow{2}{*}{$\begin{array}{l}\text { e) Temporal } \\
\text { integration of } \\
\text { the operation. }\end{array}$} & $\mathrm{X}_{15}$ : Waiting time for integration with other lines or means of transport. & $\begin{array}{l}\text { Dragu, Roman \& Roman (2013); } \\
\text { Eboli \& Mazulla (2012). }\end{array}$ \\
\hline & $\begin{array}{l}\mathrm{X}_{16} \text { : Compliance (Punctuality) of schedules defined for the lines of the } \\
\text { established intermodal network. }\end{array}$ & $\begin{array}{l}\text { Redman et al. (2013); Guirao et al. } \\
\text { (2015). }\end{array}$ \\
\hline
\end{tabular}


For any intermodal system to function effectively, it is essential to assert that, in addition to the establishment of integration points to carry out exchanges between the various means of transport, it is also necessary to provide basic infrastructure in the urban environment that allows for the orderly and segregated displacement of pedestrians, bicycles, vehicles and public passenger transport. Likewise, it is essential to provide users with clear information about the operation of the system and comply with the operational requirements for waiting times and punctuality of the vehicles.

\section{METODOLOGY}

It was necessary to develop an evaluation model, to define the operational performance priorities for intermodal passenger transport in urban environments. The steps established for the elaboration of the model observe the following sequence:

a) Construction of the theoretical framework.

According to the methodology proposed by Avni et al. (2015), the systematic literature review (SLR) was used to characterize the evolution of innovation related to the concept of intermodality applied to public transport. The search was carried out through the CAPES/MEC Journal Portal and the following keywords were used: (1) intermodality AND "public transportation"; (2) "integrated transport systems"; (3) intermodality AND "public transport".

Based on the last 5 years of searches, 153 articles were identified. After reading the title and full summary, the analysis base was reduced to 31 titles. After reading these studies in full, the research was limited to 20 titles, since 11 articles did not adhere to the research objective. In addition, 9 articles from the period prior to the last 5 years were included, as they were recurrently cited in the analyzed literature. Thus, 29 publications were used to define the theoretical framework related to the subject of intermodality in public transport.

After systematizing the selected texts, general aspects related to intermodality were highlighted - such as definition, advantages and main barriers to their implementation - and 16 variables were identified which encourage intermodal passenger transport in urban environments (Table 1).

b) Evaluation and classification of the variables used to define the performance of intermodal travel in urban passenger transport.

The evaluation and classification of the variables was established according to the importance attributed by users to the components of the intermodal passenger transport system. To accomplish this 385 questionnaires were applied. The target audience were the residents of the Metropolitan Region of Recife (RMR), state of Pernambuco, Brazil, stratified according to the total population of the cities that make up the RMR, age between 18 and 65 years, and users of the public transport system. Respondents were approached randomly on public roads, in meetings lasting an average of 20 minutes, at different times and on different days, in all cities in the RMR.

The capital of the state of Pernambuco, Recife, has a metropolitan region composed of 14 municipalities, with an estimated population of 4,054,866 inhabitants in 2018, spread over an area of approximately 3,200.00 $\mathrm{km}^{2}$ (Integrated Urban Development Plan, 2020). Its public transport interconnection model was based on the formation of the Integrated Structural System (ISS). Consisting of a network formed by bus, BRT, subway and light-rail lines, its spatial configuration is formed by radial and perimeter axes, where these axes meet at 24 integration terminals. 
The planning and management of the bus and BRT lines are carried out by the Consortium Grande Recife, who is also responsible for bidding and contracting transportation services and updating and inspecting the service concession contracts. The Companhia Brasileira de Trens Urbanos - CBTU is responsible for the operation of the subway and the light-rail. A technical cooperation agreement was formulated between them that allows passengers to change the mode of transport, only at the integration terminals, without the need to pay an additional fare. Currently, approximately 2,000,000 people are transported per day, distributed as follows: 200,000 - BRT, 400,000 - subway/light-rail and 1,400,000 - buses (Union of Passenger Transport Companies of Pernambuco, 2020).

Today, the city of Recife has $62 \mathrm{~km}$ of exclusive corridors for buses and $150 \mathrm{~km}$ of bike-paths, bike-lanes and permanent bike-routes - being quite scarce in the remaining cities of the RMR (CTTU, 2020). With regard to bicycle rentals, the main sharing program provides 80 stations with access to bikes in the cities of Recife (70 points), Olinda (5 points) and Jaboatão dos Guararapes (5 points). However, the location of the stations is concentrated in the central region of Recife and is practically nonexistent in the peripheral areas of the city and other locations in the metropolitan region (Bikepe, 2020).

The dimensioning of the sample size followed the procedure established by Pinheiro et al. (2011), for populations that present an infinite size. By calculating the sample to a 95\% confidence level $(z=1.96)$, a margin of error of $5 \%(e=0.05)$ and an expected proportion of $50 \%$ $(\mathrm{p}=0.50)$, a value of $\mathrm{n}=384.16$ is obtained as a result, that is, 385 people.

The questionnaire was divided into two parts: in the first, the questions identify the socioeconomic profile of the respondents, while in the second the interviewees evaluated the importance of the characteristic related to their choice in carrying out an intermodal displacement in urban environments. This second part presents 16 questions, one for each of the 16 variables identified in Chart 1. The Likert scale was used as a tool to assess the pattern of responses. Respondents chose one of the following positions relating the influence of the variable on the quality of the service: (5) "totally agree", (4) "partially agree", (3) "without opinion", (2) "partially disagree" "and (1)" strongly disagree ".

The exploratory factor analysis (EFA) was adopted as a model for assessing, classifying and defining the weights of the variables. The use of the exploratory factor analysis technique assumes that the variables under study have high correlations that promote groupings called factors. Beavers et al. (2013) demonstrate that each factor generated is the response to the extraction of a linear combination of variables and that they explain the largest portion of variation between them, with the first factor extracted showing the highest percentage of this variation.

The other factors have decreasing power to explain the variation portion of the variables, since each of them is a linear combination that counts the maximum amount of variation that is not included in the previous factor. The total of factors has the same number of variables used in the analysis. The correlation between factors and variables is defined as a factor load. The relative importance of each variable will be calculated from the average of its factor load as a function of the eigenvalue of each factor. Variables that do not show a significant correlation with the others will be discarded, since users understand that they explain little about the operational performance of intermodal trips.

c) Analysis of the users' perception in relation to the performance of the variables that make up the intermodal urban displacements. 
After the process of evaluating and defining the variables, a second questionnaire was used in order to measure the performance perceived by the users of the integrated passenger transport system.

An additional 385 questionnaires were applied to users of the public transport system, stratified according to the total population of the cities in the Metropolitan Region of Recife (RMR). Respondents were approached randomly in public places, at different times and days, in all cities in the RMR. The questionnaire was subdivided into two stages: in the first, the socioeconomic profile of the interviewees is investigated, in the second, 14 questions are presented to identify the population's perception regarding the performance of the intermodal transport system. The Likert scale was adopted for responses, using the following classification: (5) "totally agree", (4) "partially agree", (3) "without opinion", (2) "partially disagree" and (1) "totally disagree".

The quantitative assessment of the questionnaires was carried out through two analyzes: quartile analysis and performance index. The first arranges the classification in order of priority of the variables observed by the population with the greatest need of government intervention, to improve integration conditions in transference areas. The second defines the classification of the performance values $(M)$ obtained in the study, ordered independently of the dimensions, into four priority stages for the execution of improvements (Freitas, Manhães \& Cozendey, 2006). These are:

I. Critical priority: variables with an $M$ value lower than the value calculated for the first quartile.

II. High priority: variables with an $M$ value between the first and second quartiles.

III. Moderate priority: variables with an $M$ value between the second and third quartiles.

IV. Low priority: variables with an $M$ value contained in the third quartile.

The formulation of the performance index (Id) allows for the definition of a parameter of continuous monitoring, to verify if the population perceives the performance evolution of the intermodal system over time. Equation 1 presents the index for evaluating performance measures - Id (Cronin \& Taylor, 1992).

$I d=\sum_{x=1}^{n} P x M x$

where $\quad I d$ : operational performance index for intermodal travel;

$M x: \quad$ average operational performance identified for each variable $x$ analyzed;

$P x$ : $\quad$ importance or weighting (\%) of variable $x$;

$n: \quad$ total number of variables in the questionnaire.

The $I d$ is calculated for a scale with a variation between 1 and 5 . Thus, values calculated for Id of around 3 (three) express a regular performance, while inferior results express an unsatisfactory performance of the system, and higher amounts point to performances well evaluated by the population (Cronin \& Taylor, 1992).

\section{RESULTS}

Regarding the public surveyed in the first questionnaire, used to evaluate and classify the variables utilized to define the performance of intermodal travel in urban passenger transport, $72.98 \%$ of respondents are recurrent bus users, while $27.02 \%$ use the subway/light rail system to carry out their displacements. $48.01 \%$ of respondents use some form of integration 
(bus-bus or bus-subway/light rail to complete their journey. The average duration of trips ranges between 30-60 minutes for 35.32\% of respondents.

It is noteworthy that there is a slight predominance of the male gender in the surveyed public (52.98\% male and $47.02 \%$ female). As the income of the respondents increases, there is a reduction in the regular use of public transport $-91.43 \%$ of respondents were concentrated in the income range of up to three minimum wages. In addition, $34.29 \%$ of respondents completed high school and $68.83 \%$ are between 18 and 34 years of age.

With the data obtained in the second part of the first questionnaire, initially the exploratory factor analysis (EFA) was calculated, using the SPSS software, to assess and classify the variables that will influence the choice of intermodal urban displacements. The sample presents 385 cases that were studied in relation to 16 investigated variables. However, after extracting the factors, the commonality for variables $X_{7}$ and $X_{10}$, respectively "Free transfers between the different means of passenger transport" and "Public transportation adapted to transport bicycles", obtained the following values as a result: 0.339 and 0.330 .

According to Schwab (2007), only variables with a commonality value greater than 0.5 should be kept in the analysis. Thus, after this initial evaluation stage, these variables were removed from the EFA, since the percentage of the total variance being loaded in each of these items is very small, that is, these variables do not contribute to explaining the phenomenon under study. Subsequently, a new EFA was initiated with a sample of 385 cases studied for 14 investigated variables. The results of exploring data viability and extracting the factors are described below:

- Determinant of the correlation matrix: 0.062. Criterion: determinant must have a value greater than 0.00001. (García-Santillán et al., 2017). In other words, there is no multicollinearity problem between the variables presented.

- Adequacy measure of the Kaiser-Meyer-Olkin (KMO) sample: 0.679. Criterion: samples with $K M O>0.6$ are considered adequate (Marôco, 2014). The result found indicates that there is a total of significant correlations between the variables that underlies the application of EFA.

- Bartlett's test of sphericity: significance equal to 0.000 and statistic of Pearson's Chi Square test equal to $1,053.120$, for a critical value $\chi 95 \%, 91=114.268$. Criterion: results below 0.05 are considered significant, with statistic of Pearson's Chi Square test higher than the critical value for a significance of 0.05 (García-Santillán et al., 2017). The values found for significance and statistic of Pearson's Chi-square test attest to the existence of sufficient relationships between variables for the application of the EFA.

After confirming the possibility of applying the EFA, the factors were extracted by calculating the determinant of the correlation matrix and applying the $K M O$ and Bartlett's sphericity tests.

- Method used to extract the factors: analysis of main components.

- Total variance explained after factor extraction: The first factor $(F 1)$ is considered the most important, since it exhibits the largest portion of variance retained at $20.177 \%$, with this result decreasing for the other factors $(F 2=14.082 \%, F 3=12.339 \%$, $F 4=9.586 \%$ and $\mathrm{F} 5=7.549 \%$ ).

- When using the Kaiser criterion, factors with eigenvalue $(\lambda)$ greater than 1 were retained $\quad(\lambda 1=2.825, \quad \lambda 2=1.971, \quad \lambda 3=1.727, \quad \lambda 4=1.342, \quad \lambda 5=1.057)$. 
Thus, the first 5 factors that explain $63.733 \%$ of the variability of the 14 original variables were retained (Marôco, 2014).

As all the data showed feasibility of applying the EFA, the rotation phase of the retained factors was carried out. Through the Varimax orthogonal rotation model, the explanatory power of each factor was made more evident, by presenting the factor load in which each of the variables has the highest value. These are the variables that will form each of the factors. Table 1 shows the factor load after the rotation of the factors for each of the variables analyzed.

Table 2 - Communalities and matrix of the rotated factorial structure

\begin{tabular}{|c|c|c|c|c|c|c|c|}
\hline \multirow[b]{2}{*}{ Dimension } & \multirow[b]{2}{*}{ Communality } & \multicolumn{5}{|c|}{ Factor } & \multirow[b]{2}{*}{ Weight } \\
\hline & & 1 & 2 & 3 & 4 & 5 & \\
\hline $\begin{array}{l}X_{15} \text { : Waiting time for integration with other lines or } \\
\text { means of transport. }\end{array}$ & 0.728 & 0.849 & & & & & $12.05 \%$ \\
\hline $\mathrm{X}_{2}:$ Connectivity between boarding stations. & 0.628 & 0.772 & & & & & $10.96 \%$ \\
\hline $\mathrm{X}_{3}$ : Exclusive corridors for PT. & 0.552 & 0.716 & & & & & $10.16 \%$ \\
\hline $\begin{array}{l}\mathrm{X}_{14} \text { : Comfort and attention made available to } \\
\text { passengers. }\end{array}$ & 0.659 & & 0.793 & & & & $7.85 \%$ \\
\hline $\mathrm{X}_{1}$ : Access to boarding stations. & 0.616 & & 0.765 & & & & $7.58 \%$ \\
\hline $\begin{array}{l}\mathrm{X}_{16} \text { : Compliance (Punctuality) of the schedules } \\
\text { defined for the lines of the established intermodal } \\
\text { network. }\end{array}$ & 0.598 & & 0.762 & & & & $7.55 \%$ \\
\hline $\begin{array}{l}\mathrm{X}_{6}: \text { Availability of website/application with } \\
\text { information about PT. }\end{array}$ & 0.600 & & & 0.764 & & & $6.63 \%$ \\
\hline $\mathrm{X}_{8}:$ Visual communication of the schedules. & 0.604 & & & 0.743 & & & $6.45 \%$ \\
\hline$X_{5}$ : Single cards for boarding all means of transport. & 0.606 & & & 0.735 & & & $6.38 \%$ \\
\hline $\mathrm{X}_{12}$ : Car parking near PT stations. & 0.675 & & & & 0.810 & & $5.46 \%$ \\
\hline $\mathrm{X}_{13}$ : Presence of taxi service near PT stations. & 0.551 & & & & 0.733 & & $4.94 \%$ \\
\hline $\mathrm{X}_{11}$ : Bicycle parking near the PT. & 0.558 & & & & 0.730 & & $4.92 \%$ \\
\hline $\mathrm{X}_{9}$ : Disp. of rental bikes near PT stations. & 0.794 & & & & & 0.869 & $4.63 \%$ \\
\hline $\mathrm{X}_{9}$ : Physical separation of transit-ways & 0.755 & & & & & 0.836 & $4.44 \%$ \\
\hline Sum of the weights: & & & & & & & $100 \%$ \\
\hline
\end{tabular}

Table 1 also shows the weight (relative importance) of each variable, calculated from its factor load, weighted according to the eigenvalues $(\lambda)$ of each of the factors extracted (Silva, Silva and Borges, 2015). The variables contained in the first factor have greater weight, since it presents the largest portion of the retained variance, and this value decreases sequentially for the other factors (Beavers et al., 2013). Considering the nature of each of its constituent variables, the 5 factors shown in Table 1 are ranked in decreasing order of importance, the first factor explaining the greatest portion of variation of the original variables, and the other factors decreasing in importance. These are:

Factor 1 - Travel time. Constituent variables: $X_{15}$ - Waiting time for integration with other lines or means of transport, $X_{2}$ - Connectivity between boarding stations and $X_{3}$ - Corridors exclusive to PT.

Factor 2 - Attention provided to the passenger. Constituent variables: $X_{14}$ - Comfort and attention provided to passengers, $X_{1}$ - Access to boarding stations and $X_{16}$ - Compliance (Punctuality) of the schedules defined for the lines of the established intermodal network.

Factor 3 - Technological resources and information. Constituent variables: $X_{6}$ - Availability of website/application with information about PT, $X_{8}$ - Visual communication of the schedules and $X_{5}$ - Single cards for boarding all means of transport. 
Factor 4 - Parking for complementary transport. Constituent variables: $X_{12}$ - Car parking near PT stations, $X_{13}$ - Presence of taxi service near PT stations and $X_{11}$ - Bicycle parking near PT.

Factor 5 - Integration with bikers and pedestrians. Constituent variables: $X_{9}$ - Availability of bicycles for rent close to PT stations and $X_{4}$ - Physical separation of transit-ways.

After evaluating and classifying the variables, the second questionnaire was utilized to analyze users' perception regarding the performance of the variables that make up the intermodal urban displacements. In reference to the respondents' socioeconomic profile, the male gender was predominant $(56.10 \%)$, the largest portion of the interviewees reveals income of up to three minimum wages (88.05\%) and $31.17 \%$ has completed high school.

The bus is the main means of travel for respondents $(76.10 \%)$, while the subway/light rail system accounts for $23.9 \%$ of the public surveyed. The need to carry out some form of integration (bus-bus or bus-subway/light rail) is already a reality for most respondents (53.25\%) and $37.92 \%$ of respondents complete their journeys in 30-60 minutes.

Regarding perceived performance, Table 2 presents the values of the average operational performance $(M)$ for each of the evaluated criteria (scale of 1-5), the standard deviation calculated for the values of $M$ and the internal consistency test of the factors obtained (Cronbach's alpha). Cronbach's alpha values above 0.6 indicate that the constituent variables of each factor are homogeneous and that the scale created is consistent to measure the average operational performance of the factors that influence the formation of intermodal trips (Pestana and Gageiro, 2003).

Table 3 - Evaluation of the average operational performance $(M)$ of the factors that influence the formation of intermodal trips

\begin{tabular}{|c|c|c|c|c|c|}
\hline Factor & Item & Topic used in the questionnaire for user evaluation & $\begin{array}{l}\text { Average } \\
\text { performance }(M)\end{array}$ & $\begin{array}{l}\text { Standard } \\
\text { deviation }\end{array}$ & $\begin{array}{l}\text { Cronbach's } \\
\text { alpha }\end{array}$ \\
\hline \multirow{3}{*}{$\begin{array}{l}\text { Time of } \\
\text { travel }\end{array}$} & $\mathrm{X}_{15}$ : waiting time. & The waiting time for public transport (PT) is adequate. & 1.626 & 0.878 & \multirow{3}{*}{0.700} \\
\hline & $\mathrm{X}_{2}$ : Connectivity & $\begin{array}{l}\text { The distance I travel to get to the public transport (PT) } \\
\text { boarding stations is fast. }\end{array}$ & 2.587 & 1.316 & \\
\hline & $\begin{array}{l}\mathrm{X}_{3} \text { : Exclusive } \\
\text { corridors }\end{array}$ & $\begin{array}{l}\text { The PT exclusive lanes exist in sufficient numbers, and it is } \\
\text { rare for the PT vehicle to be stuck in traffic jams during its } \\
\text { journey. }\end{array}$ & 1.886 & 1.154 & \\
\hline \multirow{3}{*}{$\begin{array}{l}\text { Attention to } \\
\text { users }\end{array}$} & $\begin{array}{l}\mathrm{X}_{14}: \text { Comfort and } \\
\text { attention }\end{array}$ & $\begin{array}{l}\text { The waiting conditions are adequate: they offer shelter } \\
\text { and seats for waiting users, reduced lines, low noise and } \\
\text { adequate lighting at the PT boarding points. }\end{array}$ & 1.343 & 0.837 & \multirow{3}{*}{0.693} \\
\hline & $\mathrm{X}_{1}$ : Access & $\begin{array}{l}\text { The conditions for walking on the sidewalks to the PT are } \\
\text { good: evenness, without deviations, wide sidewalks, } \\
\text { absence of obstacles (garbage and holes) and easy for } \\
\text { pedestrians to pass through the crossings. }\end{array}$ & 1.543 & 0.924 & \\
\hline & $\mathrm{X}_{16:}$ Pontuality & The punctuality of the PT is high. & 1.722 & 0.934 & \\
\hline \multirow{3}{*}{$\begin{array}{l}\text { Information } \\
\text { and } \\
\text { technology }\end{array}$} & $\begin{array}{l}\mathrm{X}_{6} \text { : Site/application } \\
\text { availability }\end{array}$ & $\begin{array}{l}\text { The information available on websites and applications } \\
\text { about the public transport system is correct. }\end{array}$ & 2.823 & 1.179 & \multirow{3}{*}{0.643} \\
\hline & $\begin{array}{l}\mathrm{X}_{8}: \text { Visual } \\
\text { Communication }\end{array}$ & $\begin{array}{l}\text { The communication signs at the terminals exist and are } \\
\text { easy to understand. }\end{array}$ & 2.553 & 1.220 & \\
\hline & $\mathrm{X}_{5}:$ Smart cards & It is easy to purchase and pay for tickets. & 3.210 & 1.360 & \\
\hline \multirow{3}{*}{$\begin{array}{l}\text { Parking and } \\
\text { complemen- } \\
\text { tary trans- } \\
\text { portation }\end{array}$} & $\mathrm{X}_{12}$ : Parking for cars & $\begin{array}{l}\text { It is easy and safe to park cars and motorbikes close to } \\
\text { public transport boarding stations. }\end{array}$ & 1.649 & 0.866 & \multirow{3}{*}{0.633} \\
\hline & $\begin{array}{l}\mathrm{X}_{13}: \text { Presence of } \\
\text { taxi service }\end{array}$ & $\begin{array}{l}\text { There is always a taxi available close to the public } \\
\text { transport boarding stations. }\end{array}$ & 2.239 & 1.155 & \\
\hline & $\mathrm{X}_{11}$ : Bicycle Parking & $\begin{array}{l}\text { It is easy and safe to park bicycles close to public } \\
\text { transport boarding stations. }\end{array}$ & 1.717 & 0.947 & \\
\hline \multirow{2}{*}{$\begin{array}{l}\text { Integration } \\
\text { with bikers } \\
\text { and } \\
\text { pedestrians }\end{array}$} & $\begin{array}{l}\mathrm{X}_{9} \text { : Disp. of rental } \\
\text { bikes }\end{array}$ & $\begin{array}{l}\text { It is easy to find bicycles for rent close to public transport } \\
\text { boarding stations. }\end{array}$ & 1.621 & 0.908 & \multirow[b]{2}{*}{0.688} \\
\hline & $\begin{array}{l}\mathrm{X}_{4} \text { : Physical separa- } \\
\text { tion of transit-ways }\end{array}$ & $\begin{array}{l}\text { Pedestrians, bicycles and cars take separate paths in the } \\
\text { streets and avenues to get to the public transport } \\
\text { boarding stations. }\end{array}$ & 1.748 & 1.014 & \\
\hline
\end{tabular}


Table 2 also shows that for the surveyed users none of the parameters evaluated demonstrated a positive performance. That is, none of the values calculated for $M$ were in the range between $4-5$. Only the variable $X_{5}$ - smart cards $(M=3.210)$ indicated regular performance (3 $\leq M<4$ ), while the other variables show unsatisfactory performance, $M<3$ (Cronin \& Taylor, 1992).

In addition, the standard deviation column of Table 2 indicates how uniform the interviewees' response pattern is. The results found for variables " $X_{5}$ - smart cards", " $X_{2}$ connectivity" and " $X_{8}$ - visual communication" present the greatest dispersion for the calculation of $M$, while variables " $X_{12}$ - car parking" and " $X_{14}$ - comfort and attention" exhibit more uniform response values.

The classification of the parameters is presented below in decreasing order of priority for carrying out improvements. For quartile formation, the variables are arranged in ascending order in relation to the calculated Average Performance $(M)$. The variables of the first quartile are considered to be of critical priority, since they have a lower $M$ value and, therefore, are seen by the population as having the greatest need of intervention to improve the conditions of integration at interchange points.

- Critical priority: 1 st Quartile - Items: $X_{14}, X_{1}, X_{9}$ (limited value $=1.625$ ).

- High priority: 2nd Quartile - Items: $X_{15}, X_{12}, X_{11}, X_{16}$ (limited value $=1.735$ ).

- Moderate priority: 3rd Quartile - Items: $X_{4}, X_{3}, X_{13}, X_{8}$ (limited value $=2.565$ ).

- Low priority: 4th Quartile - Items: $X_{2}, X_{6}, X_{5}$.

In relation to the data obtained in the performance evaluation of the integrated transport system of this metropolitan region, the analysis of quartiles shows that the aspects related in the critical priority, and which would provide an improvement in the performance of passenger transport, are conditioned to an evolution in the use conditions of the active transport. The variables listed refer to the precarious conditions perceived for access (walking) and for vehicle waiting places, as well as to the need of a greater availability of rental bicycles to complement the trips.

Regarding the criteria identified as high priority, it is necessary to implement targeted measures to provide greater temporal integration of the operation (waiting time and punctuality of the vehicles). Moreover, it is important to guarantee the physical interconnection between the modes of transport, by increasing the offer of parking spaces for automobiles, motorcycles and bicycles close to the boarding stations and integration terminals, which today are quite reduced in number.

Even the characteristics listed as moderate and low priority, also show modest values of performance. Among the particularities pointed out by users as moderate preference for intervention are: improvements in infrastructure to provide greater fluidity of traffic (implementation of exclusive corridors for public transport and physical separation between transit-ways for pedestrians, bikers and car/motorcycle drivers); integration between public transport and taxi; and improvement in the visual communication of boarding stations.

The joint implementation of a greater number of exclusive lanes for public transport and the physical separation between the transit-ways for pedestrians, bikers, and car/motorcycle drivers are actions aimed at promoting intermodal trips, necessary in a city which in 2019 presented the worst traffic conditions among Brazilian cities (ANSA, 2019). 
Finally, the aspects recognized as low priority associate issues related to the distance between public transport stations, the existence of websites and applications that provide real-time information related to passenger transportation and the use of smart cards that facilitate the purchase of tickets. Together, the conditions listed above present technology as an element of convergence for its development. Regarding the connectivity of the boarding stations, expanding the program of time integration of fares (currently restricted to specific lines that correspond to less than $50 \%$ of the total) would allow users of the system greater comfort when carrying out integrated trips.

Similarly, there are softwares that facilitate the purchase of boarding fares and ensure the availability of information related to the transportation system. However, there is the difficulty in accessing the Internet, which is currently available to $79.9 \%$ of the population in the metropolitan region, but is difficult to access by the public with less purchasing power, who are the main users of the public transport system (Moraes, 2020).

The restrictions identified by the population in relation to the average operational performance $(M)$ of the factors that influence the composition of intermodal trips, are reflected in the calculation of the operational performance index for intermodal trips (Id), calculated through Equation 2.

$$
\begin{aligned}
I d= & (7,58 \% \times 1,543)+(10,96 \% \times 2,587)+(10,16 \% \times 1,886)+(4,44 \% \times 1,748) \\
& +(6,38 \% \times 3,21)+(6,63 \% \times 2,823)+(6,45 \% \times 2,553)+(4,62 \% \times 1,621) \\
& +(4,92 \% \times 1,717)+(5,46 \% \times 1,649)+(4,94 \% \times 2,239)+(7,85 \% \times 1,343) \\
& +(12,05 \% \times 1,626)+(7,55 \% \times 1,722)=2,018
\end{aligned}
$$

The value calculated for the operational performance index for intermodal trips ( $\mathrm{Id}=2.018$ ) reflects that, although alternative modes of travel are available, users do not perceive a degree of integration between their operations that allows them to travel door to door using more than one form of transport, in a satisfactorily integrated manner. This in turn can result in longer and less comfortable journeys, and encourages a reduction in the number of users of the passenger transport system.

The continuous monitoring of the priority classification will help managers direct improvements according to users' perception, while the evaluation through the index (Id) will enable the measuring and monitoring of results of interventions performed over time.

\section{FINAL CONSIDERATIONS}

Stimulating the development of intermodal travel represents an important step towards promoting sustainable mobility, allowing passengers greater accessibility, promoting a greater number of origin-destination connections and fostering the consolidation of a system in which public transport is the pillar of an integrated network with other complementary forms of locomotion.

The elaboration of an instrument of operational evaluation for intermodal trips allowed the identification of the critical points of the system, so that defined and monitored actions can be directed towards its improvement. The application of the evaluation model in the Integrated Transport System of the Metropolitan Region of Recife, Pernambuco, Brazil, demonstrates the difficulties perceived by users in making journeys composed by different modes of transport.

This evaluation reveals the adversities faced by bikers, pedestrians and people with reduced mobility to complement an intermodal trip in the area under analysis, since the indicators related to the infrastructure of public spaces that lead to interchange stations reveal several 
points of weakness. The waiting time and the conditions of discomfort imposed on users reinforce the need for better and greater connectivity between the various forms of travel, in order to provide passengers with a greater number of alternatives for getting around.

It is worth mentioning that this study asserts that success in developing intermodality is not restricted only to offering a greater number of means of transport for the population to make their trips. The importance of the infrastructure made available in the urban space confirms the need for enhanced activities that consider the entire circulation environment. Thus, in order to strengthen the metropolitan transport system, the aim is to guarantee the complete adequacy of the trajectory, the operational measures that coordinate the modes of transport and the provision of technological resources to help users with the information necessary to have the best possible conditions in their journey.

The results found confirm the relevance of the proposed model as an instrument of managerial control and highlight the priority elements for the elaboration of public policies and improvement interventions in integrated passenger transport systems. As a suggestion for future studies, we recommend the application of this research in different locations, with different integrated transport systems, to verify if there are specific conditions that may portray possible similarities and distinctions in the results.

\section{REFERENCES}

Agência ANSA (2019). Recife tem o 10o pior trânsito do mundo, diz pesquisa. Revista Época Negócios. Available at: https://epocanegocios.globo.com/Brasil/noticia/2019/06/recife-tem-o-10-pior-transito-do-mundo-diz-pesquisa.html. (Accessed: 21/June/2020).

Avni, A.; Burley, P.; Casey, P.; Cherney, J.; Christiansen, L.; Daly, J. S.; Evans, R.; Jared, D.; Landgraf, G.; Meier, A.; Minotti, J.; Post, B.; Sandstedt, B.; Sarmiento, R.; Sillick, S.; Sweet, B.; Wendt, M.; Winter, K. and Yu, H. (2015). Literature searches and literature reviews for transportation research projects. How to Search, Where to Search, and How to Put It All Together: Current Practices. Transportation Research E-Circular (E-C194). Available at: http://www.trb.org/Main/Blurbs/172271.aspx. (Accessed: 15/may/2020).

Barnfield, A. and Plyushteva, A. (2016). Cycling in the post-socialist city: On travelling by bicycle in Sofia, Bulgaria. Urban Studies, v. 53, n. 9, p. 1822-1835. DOI: 10.1177/0042098015586536

Beavers, A. S.; Lounsbury, J. W.; Richards, J. K. and Huck, S. W. (2013). Practical considerations for using exploratory factor analysis in educational research. Practical Assessment, Research, and Evaluation, v. 18, n. 1, p. 1-13. D0I:10.7275/qv2qrk76

Becker, J. U. and Albers, S. (2016). The limits of analyzing service quality data in public transport. Transportation, v. 43, n. 5, p. 823-842. DOI:10.1007/s11116-015-9621-2

Bikepe (2021) Bike Pernambuco. Available at: http://bikeitau.com.br/bikepe. (Accessed: 10/May/2021).

Brons, M.; Givoni, M. and Rietveld, P. (2009). Access to railway stations and its potential in increasing rail use. Transportation Research Part A: Policy and Practice, v. 43, n. 2, p. 136-149. DOI: 10.1016/j.tra.2008.08.002

Buehler, R. (2012). Determinants of bicycle commuting in the Washington, DC region: The role of bicycle parking, cyclist showers, and free car parking at work. Transportation Research Part D: Transport and Environment, v. 17, n. 7, p. 525-531. DOI:10.1016/j.trd.2012.06.003

Chowdhury, S. and Ceder, A. (2013). A psychological investigation on public-transport users' intention to use routes with transfers. International Journal of Transportation, v. 1, n. 1, p. 1-20. DOI: 10.14257/ijt.2013.1.1.01

Chowdhury, S.; Hadas, Y.; Gonzalez, V. A. and Schot, B. (2018). Public transport users' and policy makers' perceptions of integrated public transport systems. Transport Policy, v. 61, p. 75-83. DOI: 10.1016/j.tranpol.2017.10.001

Correia, J. (2017). Information for Urban Intermodal Transport. U. Porto Journal of Engineering, v. 3, n. 1, p. 61-71. DOI: 10.24840/2183-6493_003.001_0006

Cronin Jr, J. J. and Taylor, S. A. (1992). Measuring service quality: a reexamination and extension. Journal of Marketing, v. 56, n. 3, p. 55-68. DOI: $10.1177 / 002224299205600304$

CTTU - Autarquia de Trânsito e Transporte Urbano do Recife (2021) Malha Cicloviária do Recife. Available at: http://dados.recife.pe.gov.br/ne/dataset/malha-cicloviaria-do-recife_(Accessed: 10/May/2021).

Dragu, V.; Roman, E. A. and ROMAN, V. C. (2013). Quality assessment in urban public transport. Theoretical and Empirical Researches in Urban Management, v. 8, n. 3, p. 32-43. Available at: https://www.jstor.org/stable/24873355. (Accessed: 12/March/2020).

Eboli, L.; Fu, Y. and Mazzulla, G. (2016). Multilevel comprehensive evaluation of the railway service quality. Procedia Engineering, v. 137, n. 4, p. 21-30. DOI: 10.1016/j.proeng.2016.01.230 
Eboli, L. and Mazzulla, G. (2012) Performance indicators for an objective measure of public transport service quality, European Transport - Trasporti Europei, v. 51, n. 3, p. 1-21. Available at: http://hdl.handle.net/10077/6119. (Accessed: 08/April/2020).

Ferraz, A. C. P. and Torres, I. G. E. (2001). Transporte público urbano. Rima, São Carlos, SP.

Freitas, A.L.P.; Manhães, N.R.C. and Cozendey, M.I. (2006) Emprego do SERVQUAL na avaliação da qualidade de serviços de Tecnologia da Informação: uma análise experimental. In Anais do XXVI Encontro Nacional de Engenharia de Produção. Fortaleza, Ceará, Brasil.

Fu, Y.; Eboli, L.; Mazzulla, G. and Zhang, Y. (2017). Railway service quality in northern Italy: A multilevel synthetic assessment. Advances in Mechanical Engineering, v. 9, n. 3, p. 1-12. DOI: 10.1177/1687814016686317

García-Santillán, A.; Rojas-Kramer, C.; Moreno-García, E. and Ramos-Hernández, J. (2017). Mathematics test, numerical task and mathematics course as determinants of anxiety toward math on college students. European Journal of Contemporary Education, v. 6, n. 2, p. 240-253. DOI: 10.13187/ejced.2017.2.240

Guirao, B.; García, A.; López, M. E.; Acha, C. and Comendador, J. (2015) New QR survey methodologies to analyze user perception of service quality in public transport: the experience of Madrid. Journal of Public Transportation, v. 18, n. 3, p. 71-88. DOI: $10.5038 / 2375-0901.18 .3 .5$

Hernandez, S. and Monzon, A. (2016) Key factors for defining an efficient urban transport interchange: Users' perceptions. Cities, v. 50, p. 158-167. DOI: 10.1016/j.cities.2015.09.009

Janic, M. (2010) Integrated transport systems in the European Union: an overview of some recent developments. Transport Reviews, v. 21, n. 4, p. 469-497. DOI: 10.1080/01441640110042147

Litman, T. (2017) Introduction to multi-modal transportation planning. Victoria Transport Policy Institute. Available at: http://www.vtpi.org/multimodal_planning.pdf. (Accessed: 02/June/2020).

Lois, D.; Monzón, A. and Hernández, S. (2018). Analysis of satisfaction factors at urban transport interchanges: Measuring travellers' attitudes to information, security and waiting. Transport Policy, v. 67, p. 49-56. DOI: 10.1016/j.tranpol.2017.04.004

Lucietti, L.; Hoogendoorn, C. and Cré, I. (2016). New tools and strategies for design and operation of urban transport interchanges. Transportation Research Procedia, v. 14, p. 1240-1249. DOI: 10.1016/j.trpro.2016.05.195

Mano, G. and Ribeiro, R. (2015). Cidade caminháveis: uma análise sobre o deslocamento de pedestres no centro de Ribeirão Preto-SP. In 4⿳a Conferência da Rede Lusófona de Morfologia Urbana. Brasília, Distrito Federal, Brasil.

Marôco, J. (2014). Análise Estatística com o SPSS Statistics 6th, Report Number, Lisbon, PT.

Monzón, A.; Hernández, S. and Di Ciommo, F. (2016). Efficient urban interchanges: the City-HUB model. Transportation Research Procedia, v. 14, p. 1124-1133. DOI: 10.1016/j.trpro.2016.05.183

Moraes, L. (2020, April 29) Em Pernambuco, 908 mil casas não têm acesso à internet por falta de dinheiro ou porque as pessoas não sabem usá-la. Available at: https://jc.ne10.uol.com.br/economia/2020/04/5607642-faltam-dinheiro-e-habilidadede-uso-para-908-mil-lares-de-pernambuco-terem-acesso-a-internet.html. (Accessed: 03/August/2020).

Nathanail, E.; Adamos, G.; Tsami, M. and Jackiva, I. Y. (2018) Green Urban Interchanges: Stakeholder and User Perspectives. Transport and Telecommunication Journal, v. 19, n. 3, p. 183-193. DOI: 10.2478/ttj-2018-0015

Olekszechen, N.; Battiston, M. and Kuhnen, A. (2016) Bicycle as a mean of transportation on person-environment studies. Desenvolvimento e Meio Ambiente, v. 36, p. 355-369. DOI:10.5380/dma.v36i0.43654.

Plano de Desenvolvimento Urbano Integrado (PDUI) (2020). Plano de Desenvolvimento Urbano Integrado da Região Metropolitana do Recife. Available at: https://www.pdui-rmr.pe.gov.br/RMR. (Accessed: 10/June/2020).

Pestana, M. H. and Gageiro, J. N. (2008). Análise de dados para ciências sociais: a complementaridade do SPSS. 3th, Edições Silabo, Lisbon, PT.

Piatkowski, D.; Bronson, R.; Marshall, W. and Krizek, K. J. (2015). Measuring the impacts of bike-to-work day events and identifying barriers to increased commuter cycling. Journal of Urban Planning and Development, v. 141, n. 4, p. 04014034 1-9. DOI: 10.1061/(ASCE)UP.1943-5444.0000239

Pinheiro, R. M.; Castro, G. C.; Silva, H. H. and Nunes, J. M. G. (2011) Pesquisa de mercado, Editora FGV, Rio de Janeiro, RJ.

Pitsiava-Latinopoulou, M. and Iordanopoulos, P. (2012) Intermodal passengers terminals: Design standards for better level of service. Procedia-Social and Behavioral Sciences, v. 48, p. 3297-3306. DOI: 10.1016/j.sbspro.2012.06.1295

Redman, L.; Friman, M.; Gärling, T. and Hartig, T. (2013) Quality attributes of public transport that attract car users: A research review. Transport Policy, v. 25, p. 119-127. DOI: 10.1016/j.tranpol.2012.11.005

Scheiner, J.; Chatterjee, K. and Heinen, E. (2016). Key events and multimodality: A life course approach. Transportation Research Part A: Policy and Practice, v. 91, p. 148-165. DOI: 10.1016/j.tra.2016.06.028

Schwab, A. J. (2007). Eletronic Classroom. [Online]. Available at: http://www.utexas.edu/ssw/eclassroom/schwab.html. (Accessed: 10/June/2020).

Silva, M.; Silva, J. D. and Borges, E. (2015) Análises de Componentes Principais para Elaborar Índices de Desempenho No Setor Público. Revista Brasileira de Biometria, São Paulo, v. 33, n. 3, p. 291-309. DOI: 10.2139/ssrn.2828289

Sindicato das Empresas de Transporte de Passageiros de Pernambuco (URBANA-PE) (2020) O Sistema de Transporte. Available at: http://urbana-pe.com.br/sobre/o-sistema-de-transporte. (Accessed: 15/june/2020).

Wang, Y.; Monzon, A. and Di Ciommo, F. (2015). Assessing the accessibility impact of transport policy by a land-use and transport interaction model-The case of Madrid. Computers, environment and urban systems, v. 49, p. 126-135. DOI: 10.1016/j.compenvurbsys.2014.03.005 
Willing, C.; Brandt, T. and Neumann, D. Intermodal mobility. (2017). Business \& Information Systems Engineering, v. 59, n. 3, p. 173-179. DOI: $10.1007 / \mathrm{s} 12599-017-0471-7$

Woldeamanuel, M. and Kent, A. (2015). Measuring walk access to transit in terms of sidewalk availability, quality, and connectivity. Journal of Urban Planning and Development, v. 142, n. 2, p. 04015019 1-13. DOI: 10.1061/(ASCE)UP.19435444.0000296 